\title{
A Cross Examination of the Intention to Integrate MOOCs in Teaching and Learning: An Application of Multi- Group Invariance Analysis
}

\author{
https://doi.org/10.3991/ijet.v14i19.10642 \\ Kung-Teck Wong ${ }^{\left({ }^{凶}\right)}$, Norazilawati binti Abdullah, Pauline Swee Choo Goh \\ Sultan Idris Education Univeristy, Perak, Malaysia \\ thomasefpm. upsi.edu.my
}

\begin{abstract}
This paper attempts to understand student teachers' and practicing teachers' integration of MOOCs in teaching and learning and build a model that predicts the intention of integration of MOOCs among them. Five variables (performance expectancy (FE), effort expectancy (EE), social influence (SI), facilitating condition (FC) and behavioural intention (BI)) were selected to build a model for the study. Structural equation modelling (SEM) was used as the main technique for the data analysis. The suggested model was found reliable and valid, based on a self-reported survey of 135 student teachers and practicing teachers. Results showed that behavioural intention toward MOOCs was significantly explained by performance expectancy and facilitating condition. Overall, of the four hypotheses, two were supported by the data. Differences were, however, detected between student teachers and practicing teachers in terms of SI and FC towards BI regards to MOOCs intention of integration.
\end{abstract}

Keywords-Technology acceptance, student teachers, practicing teachers, structural equation modeling

\section{Introduction}

With the advancement of Internet and the proliferation of educational technology, the Massive Open Online courses (MOOCs) has become a seemingly ubiquitous part of our educational systems and ushered in a new area of education technology. MOOCs is the combination of e-learning and traditional instructional paradigm. MOOCs learning has taken advantages of e-learning and traditional pedagogical practices to create differentiated instructional. Mixture of difference pedagogical practices, teaching tools and media formats is the key element in developing the blended elearning approach [1 - 3]. MOOCs in the context of school environment is different from pure E-learning practices. All courses are delivered online through the platform where students complete activities and interact with their peers within highly engaging learning communities. Anyone can enroll and start learning for free. MOOC is a set of learning strategies or dimensions that mixes various event-based activities, 
including traditional learning method, synchronous online and asynchronous selfpaced teaching and learning [4 -5].

There is a growing corpus of research that suggests that the use of MOOCs learning improves teaching and learning in developed countries [6-7]. The study by [7] revealed that learners able to achieve higher grades when teachers using MOOCs in teaching and learning. Furthermore, students can learn more skills throughout the integration of MOOCs. Many findings have either direct or indirectly indicated that MOOCs is a new generation teaching and learning which significantly more likely to encourage engagement of digital learners in teaching and learning if compare to other teaching tools. Furthermore, it has a profound impact on students' achievement with the help of rich collaborative learning communities.

\section{The Study}

With the innovation and web-based commercialization of educational technology, blended e-learning or as hybrid learning environment has been widely employed in the teacher institutions throughout Malaysia. In response to that, many teacher educators in teacher institutions and universities across the nation have been particularly aggressive and drawn significant attention in integrating conventional teaching method (most often face-to-face) with online education concept in delivering content to students and assess learning using assignments or quizzes. It is noteworthy to point out that evidence from research on blended e-learning (hybrid learning) in various settings have revealed the affordances of engaging blended e-learning platform in teaching and learning $[8-9]$.

Indeed, implementation of hybrid learning has been the top priority in the agenda of Ministry of Education (MOE), Malaysia as they understand the importance of hybrid learning in teaching and learning. Underlying 1 BestariNet, an initiative by the Education MOE, all public schools in Malaysia connected through high speed Internet with Frog Virtual Learning Environment (VLE) platform in year 2020.

While the advantages of integrating technology into educational programs have received extensive attention among researchers [10] [11], not many studies have been carried out to understand student teachers' intention to integrate MOOCs, especially in the context of teaching and learning. Given the crucial role of student teachers and practicing teachers in the process of technology implementation and the limited studies in this context, understanding student teachers' and practicing teachers' intention to integrate MOOCs in teaching and learning is a worthwhile issue of enquiry. Furthermore, in fact, MOOCs is a relatively new teaching practice in schools and the introduction of this pedagogical practice is still in an immature stage.

In response to the aforesaid gap and in order to decipher between the myriad of potential uses of MOOCs in schools and teaching institutions and with the concern about future development of MOOCs among schools teachers, the current research project aimed to understand the factors driven to the intention of integration of MOOCs in teaching and learning and conceptualize the practicing model. 
Given the immature stage of the integration of MOOCs in Malaysia context, this paper also focusses in a cross-paradigm to predict the factors affecting student teachers and practicing teachers of MOOCs integration. This shift in focus is vital to provide management insight into developing effective strategies that will allow teacher educators and curriculum planners to design new training syllabus for or pre-service teacher regards to the hybrid or blended learning instructional. Also, undoubtedly, this ensures that the new upcoming teachers and practicing teachers are comfortable and capable in new promising learning approach.

\section{Theoretical Framework}

Intention to integrate technology has been a topic that has occupied researchers for the last two decades. Various theoretical models have emerged to understanding variables that cause individuals to accept, reject or continue the use of new technology, [12 - 14]. UTAUT by [14] model has become one of the most recently tested models in in explaining user behavior across a broad range of end-user in technology integration [15], [2], [16] and [17]. The UTAUT model aims to explain users' intention to use an information system and their subsequent usage behaviour. This model was validated and found to have an $R^{2}$ of $70 \%$, indicating that the model explains $70 \%$ of the variance in user intentions to use technologies, thereby outperforming its originating models [14].

Congruent with those findings, the theoretical grounding for exploring factors influencing the intention of student teachers' and practicing teachers' intention towards MOOCs in teaching and learning is drawn based on the Unified Theory of Acceptance and Use of Technology (UTAUT) model. Notwithstanding, researchers believe that those factors are able to explain clearly about implementation of educational technology environment in Malaysia schools and institutions as a whole.

\section{$4 \quad$ Objectives}

- To develop an instrument for assess the intention of MOOCs Learning practices scale.

- Developing a model to explain factors driving the intention of integrating MOOCs pedagogical practices among student teachers and practicing teachers graduated from UPSI.

- To examine the multi-group moderation different between student teachers and practicing teachers of the intention of integrating MOOCs.

\section{$5 \quad$ Hypothesis}

- H1 Performance Expectancy (PE) will significantly and positively influence student teachers' and practicing teachers' Behavioral Intention (BI). 
- H2 Effort Expectancy (EE) will significantly and positively influence student teachers' and practicing teachers' Behavioral Intention (BI).

- H3 Social Influence (SI) will significantly and positively influence student teachers' and practicing teachers' Behavioral Intention (BI).

- H4 Facilitating condition (FC) will significantly and positively influence student teachers' and practicing teachers' Behavioral Intention (BI).

\section{$6 \quad$ Methodology}

\subsection{Measures of the constructs}

The study has employed self-report questionnaires to gather the information from the samples. The samples were asked to provide demographic and scales measuring the related variables in the suggested model which consisted of performance expectancy (PE), effort expectancy (EE), social influence (SI), facilitating condition (FC) and behavioral intention (BI). All samples were wholly voluntary and no course credits were given. All the 15 items related PE, EE, SI, FC and BI were presented in English. Structural Equation Modeling (SEM) has been used to assess the intention to use MOOC learning practices between student teachers and practicing teachers. Based on the pass studies, SEM is widely used to predict and explore the intention of technologies uses and explains the best predicting model fits. Indeed, SEM is commonly employed for the studies related to educational setting [18], [2], [10]. The AMOS statistics software program was carried out in this research [19-20].

\subsection{Setting and sample}

In this study, stratified systematic sampling will be carried out. Stratified systematic sampling is a process in which certain subgroup, or strata, is selected for the sample in the same proportion as they exist in the population and ensure that the samples are representative of the actual population and that there is no bias in the selection of the respondents. In the present study, the population will cover throughout student teachers and practicing teachers. This sampling design would increase the likelihood of representativeness of the population. A total of 135 samples, representing a response rate of $95.3 \%$, have completed the self-report questionnaire. Among these samples, $72.59 \%$ (98) were female and this phenomenon was inevitable due to the cultural preponderance of female teachers in Malaysia society. From 135 samples, 53.3\% (72) were student teachers and $43.7 \%$ (59) were practicing teachers. 


\section{$7 \quad$ Findings}

\subsection{Measurement model validation}

A confirmatory factor analysis (CFA) was carried out to examining individual factor loadings of the 15 items related PE, EE, SI, FC and BI through AMOS. Table 1 shows the result of the CFA. The individual factor loadings for all the items are higher than 0.64 . The results indicated that at least half the variances in all the items were explained by the respective latent constructs. Indeed, the model explained $64.3 \%$ of the total variance.

Average variance extracted (AVE) was carried out to test the convergent validity of the measurement model. The index results of AVE has indicated that the model is suitable for testing structural equation modelling, which should more or exceed 0.05 (Gaskin, 2018a; Gaskin, 2018b; Hair, et al. 2014; Newsom, 2017). The composite reliability (CR) measurement was carried out using Cronbach's alpha. The CR for all the factors in the measurement model ranges from 0.52 to 0.78 and it has exceeded the threshold value (0.05).

Table 1. Results of the measurement model

\begin{tabular}{|c|c|c|c|c|}
\hline \multirow[b]{2}{*}{ Latent Variable } & \multirow[b]{2}{*}{ Item } & Factor & $\begin{array}{c}\text { Average Variance } \\
\text { Extracted }^{b}\end{array}$ & Composite Reliability $^{c}$ \\
\hline & & Loading & $(\geq .50) *$ & $(\geq .50)^{*}$ \\
\hline \multirow[t]{2}{*}{ BI } & BI1 & 0.638 & \multirow[t]{2}{*}{0.58} & \multirow{2}{*}{0.52} \\
\hline & BI2 & 0.863 & & \\
\hline \multirow{3}{*}{ PE } & PE1 & 0.748 & \multirow{3}{*}{0.6} & \multirow{3}{*}{0.73} \\
\hline & PE2 & 0.776 & & \\
\hline & PE3 & 0.807 & & \\
\hline \multirow{4}{*}{$\mathrm{EE}$} & EE1 & 0.788 & \multirow{4}{*}{0.59} & \multirow{4}{*}{0.78} \\
\hline & EE2 & 0.788 & & \\
\hline & EE3 & 0.809 & & \\
\hline & EE4 & 0.692 & & \\
\hline \multirow{3}{*}{ SI } & SI1 & 0.786 & \multirow{3}{*}{0.62} & \multirow{3}{*}{0.68} \\
\hline & SI2 & 0.849 & & \\
\hline & SI3 & 0.716 & & \\
\hline \multirow{3}{*}{ FC } & FC1 & 0.708 & \multirow{3}{*}{0.63} & \multirow{3}{*}{0.73} \\
\hline & $\mathrm{FC} 2$ & 0.872 & & \\
\hline & FC3 & 0.788 & & \\
\hline
\end{tabular}

${ }^{a}$ t-Value (critical ratio) shows whether the parameter is significant at the .05 level.

${ }^{b}$ AVE: Average Variance Extracted $=\left(\sum \lambda 2\right) /\left(\sum \lambda 2\right)+\left(\sum(1-\lambda 2)\right)$.

${ }^{c}$. Composite Reliability $=\left(\sum \lambda 2\right) /\left(\sum \lambda 2\right)+\left(\sum(1-\lambda 2)\right)$.

SRE: Standardised regression weight.

Table 2 shows that results of discriminant validity of the measured items of the constructs. Through the discriminant validity results, it can compare the shared variance between factors with the AVE of the individual factors. If the square roots of the AVEs are greater than the off-diagonal elements in the corresponding rows and col- 
umns, it shows that the construct has stronger correlation with its indicators than with the other construct in the model [6]. Table 2 shows the shared variances between factors were lower than the AVE of the individual factors, suggesting that discriminant validity was present in the proposed model.

Table 2. Discriminant validity for measurement model

\begin{tabular}{|l|c|c|c|c|c|}
\hline & PE & EE & SI & FC & BI \\
\hline PE & -0.77 & & & & \\
\hline EE & 0.1 & -0.77 & & & \\
\hline SI & $.23^{*}$ & 0.05 & -0.78 & & \\
\hline FC & 0.08 & $.15^{* *}$ & 0.19 & -0.79 & \\
\hline BI & $.34^{*}$ & $.20^{*}$ & $.08^{*}$ & $.26^{*}$ & -0.76 \\
\hline
\end{tabular}

Note: Diagonal in parentheses are square root of average variance extracted from observed variables (items); Off-diagonal: correlations between constructs. $* \mathrm{p}<.05 ; * * \mathrm{p}<.01$.

\subsection{Test of the measurement model and structural model}

The five absolute fit indices: ratio of $\chi^{2}$ to its degree of freedom $\left(\chi^{2} / \mathrm{df}\right)$, Goodness of Fit (GFI), Comparative Fit Index (CFI), Tucker-Lewis Index (TLI), and Standardised Root Mean Square Error of Approximation (RMSEA) were employed in order to check model fit of the measurement model. Absolute fit indices measure how well the proposed model reproduces the observed data. According [21], the value of GFI and CFI should be more than 0.95 and that of the RMSEA smaller than 0.05 to be considered good fit. For $\chi^{2} / d f$, the value below 3 is considered acceptable. Finally, the TLI value should be greater than 0.90. As shown in Table 3, all values are above the recommended thresholds for acceptable model fit and it confirms that the measurement model has exhibited a good fit.

Table 3. Good-of-fit indices for the measurement model and structural model

\begin{tabular}{|l|c|c|c|}
\hline Fit indices & $\begin{array}{c}\text { Values of measurement } \\
\text { model }\end{array}$ & $\begin{array}{c}\text { Values of } \\
\text { structural model }\end{array}$ & Criteria $^{\mathrm{a}}$ \\
\hline$\chi^{2}$ Statistic & $\mathbf{1 0 7 . 6 9 0 * *}$ & $\mathbf{8 6 . 1 7 3} * *$ & $\begin{array}{c}\text { Insignificant but significant p- } \\
\text { value can be expected }\end{array}$ \\
\hline$\chi^{2} / d f$ & 1.6 & 1.23 & $<3$ \\
\hline RMSEA & 0.67 & 0.04 & $<0.08$ \\
\hline GFI & 0.9 & 0.92 & $\geq 0.90$ \\
\hline CFI & 0.9 & 0.96 & $\geq 0.90$ \\
\hline TLI & 0.88 & 0.95 & $\geq 0.90$ \\
\hline
\end{tabular}

${ }^{\text {a }}$ References were taken from Hair et al. [21]** $p<.01$.

\section{$8 \quad$ Hypothesis Testing}

Table 4 shows the results of the hypothesis testing and its path coefficients of the proposed research model. 
Table 4. Hypothesis testing results

\begin{tabular}{|l|l|c|l|l|}
\hline \multicolumn{1}{|c|}{ Hypotheses } & \multicolumn{1}{c|}{ Path } & Path Coefficient & \multicolumn{1}{c|}{ Hypothesis } & \multicolumn{1}{c|}{ Results } \\
\hline H1 & PE $\rightarrow$ BI & $.67^{* *}$ & Positive & Supported \\
\hline H2 & EE $\rightarrow$ BI & .17 & Positive & Not Supported \\
\hline H3 & SI $\rightarrow$ BI & .05 & Positive & Not Supported \\
\hline H4 & FC $\rightarrow$ BI & $.40^{* *}$ & Positive & Supported \\
\hline
\end{tabular}

$* \mathrm{p}<.05 ; * * \mathrm{p}<.01 ; \mathrm{ns}=$ not significant

Table 5 shows the results of the hypothesis test and path coefficient of the proposed model. $\mathrm{H} 1$ and $\mathrm{H} 4$ were supported by the data. The two endogenous variables (PE and FC) were found to be the predictors for the intention to use MOOC learning practices between student teachers and practising teachers, resulting in an $R^{2}$ of 0.341 . That is, PE and FC have explained $34.1 \%$ of the variance in the intention to use MOOC.

In order to investigate different between student teachers and practising teachers toward the intention to use MOOC, the multi- group (sub-group) invariance analysis was carried out to identify its part coefficients. This was carried out by constraining each path coefficient to be equal across the two groups. BE $\rightarrow$ BI was not included in path-by-path comparison as both were not significant in unconstrained model.

Figure 1: Significant differences standardised path coefficients for student teachers and practising teachers.

Table 5. Path-by-path comparison for the student teachers and the practising teachers group

\begin{tabular}{|l|c|c|c|}
\hline & $\chi^{\mathbf{2}}$ & $\boldsymbol{D f}$ & $\boldsymbol{\Delta} \boldsymbol{\chi}^{\mathbf{2}}$ from revised model \\
\hline Unconstrained model $^{\mathrm{a}}$ & 89.646 & 80 & \\
\hline Constrained paths & & & \\
\hline $\mathrm{PE} \rightarrow \mathrm{BI}$ & & 81 & $0.02(\mathrm{~ns})$ \\
\hline $\mathrm{SI} \rightarrow \mathrm{BI}$ & 89.663 & 81 & $14.10^{* *}$ \\
\hline $\mathrm{FC} \rightarrow \mathrm{BI}$ & 103.748 & 81 & $4.60^{*}$ \\
\hline
\end{tabular}

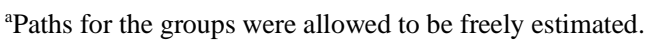

${ }^{\mathrm{b}}$ The path specified was constrained to be equal across the two groups.

$* \mathrm{p}<.05 ; * * \mathrm{p}<.01 ; \mathrm{ns}=$ not significant 


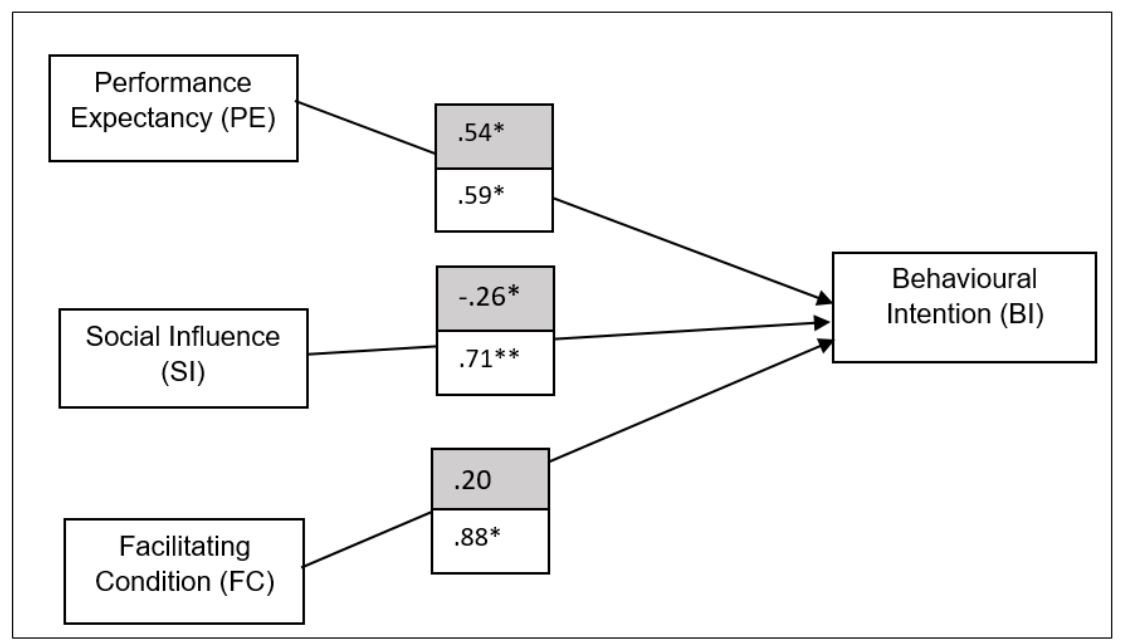

Fig. 1. Significant differences standardised path coefficients for student teachers and practising teachers

Coefficients for student teachers are in the grey shaded boxes.

$* \mathrm{p}<.05 ; * * \mathrm{p}<.01 ; \mathrm{ns}=$ not significant

\section{$9 \quad$ Discussion and Conclusion}

This study aims to examine the key predictors underlying student teachers' and practicing teachers' intention to integrate MOOCs in teaching and learning. The findings of this study offer several important implications for the study related to MOOCs integration among student teachers and practising teachers. Based on the suggested model, the findings indicated that performance expectancy, social influence and facilitating condition have significant effect on behavioural intention to integrate MOOCs in teaching and learning, while effort expectancy does not. Overall, the model accounted for $34.1 \%$ of the variance in BI to integrate MOOCs. This suggests that the research model is fairly efficient as a model to predict the behavioural intention to integrate MOOCs among Malaysian student teachers and practicing teachers.

Undoubtedly, PE, SI and FC were found to have a significant influence on BI. All constructs were fundamental constructs in the Unified Theory of Acceptance and Use of Technology (UTAUT) model [14], Theory of Reasoned Action (TRA) [22] and the Technology Acceptance Model (TAM) [23]. The findings are in line with empirical evidence from [24], 15], [25], [6], [16], [17], [26].

Unexpected vital and interesting finding was that SI to BI has a significant negative influence among student teachers. When SI go up by 1 unit, BI for student teachers will go down by 0.26 . It is reasonable to expect that the roles of student teachers and practising teachers are different. Student teachers are preferring to do something different from their peers. It was also further revealed that FC to BI was not significant 
for student teachers. Hence, to further clarify this issue, it is necessary to conduct study on this matter.

\section{Acknowledgement}

Great appreciation is communicated to Sultan Idris Education University (UPSI), Perak, Malaysia (Research grant: 2018-0030-107-01) and the Ministry of Education (MOE) Malaysia for the support of this research.

\section{References}

[1] Lee, L.-T., \& Hung, J. C. (2015). Effects of blended e-learning: a case study in higher education tax learning setting. Human-centric Computing and Information Sciences, 5(1), 13. https://doi.org/10.1186/s13673-015-0024-3

[2] Sami S. B., Malcolm J. R., Sally S. (2019). Extending the Technology Acceptance Model to Understand Students' use of Learning Management Systems in Saudi Higher Education. International Journal of Emerging Technologies in Learning (iJET), 14(3), pp. 4-21. https://doi.org/10.3991/ijet.v14i03.9732

[3] Shin, W. S., \& Kang, M. (2015). The use of a mobile learning management system at an online university and its effect on learning satisfaction and achievement. International Review of Research in Open and Distributed Learning, 16(3), 110-130. https://doi.org/10. 19173/irrodl.v16i3.1984

[4] Vatanartiran, S., \& Karadeniz, S. (2015). A needs analysis for technology integration plan: challenges and needs of teachers. Contemporary Educational Technology, 6(3), 206-220.

[5] Xin, H., Kempland, M., \& Blankson, F. H. (2015). Adaptability and replicability of webfacilitated, hybrid, and online learning in an undergraduate exercise psychology course. Turkish Online Journal of Educational Technology, 14(1), 19-30.

[6] Wong, K.T., Hwang, G.J. \& Goh, P. S.C. \& Khadijah A. (2018). Effects of blended learning pedagogical practices on students' motivation and autonomy for the teaching of short stories in upper secondary English. Interactive Learning Environments. 1-14. 10.1080/10494820.2018.1542318. https://doi.org/10.1080/10494820.2018.1542318

[7] Escobar-Rodriguez, T., \& Monge-Lozano, P. (2012). The acceptance of Moodle technology by business administration students. Computers \& Education, 58(4), 1085-1093. https:// doi.org/10.1016/j.compedu.2011.11.012

[8] Matar, N. (2017). Defining E-Learning Level of Use in Jordanian Universities Using

[9] Sabbah, S. S. (2016). The Effect of Study Habits on English Language Achievement. Arab World English Journal (AWEJ) 7(4), 238-257. https://doi.org/10.24093/awej/vol7no4.16

[10] Newsom, J. (2017). Improper solutions in SEM. Retrived on December 15, 2018 from http://web.pdx.edu/ newsomj.

[11] Harlow, A., Cowie, B. and Heazlewood, M. (2010). Keeping in touch with learning: the use of an interactive whiteboard in the junior school. Technology, Pedagogy and Education, 2(19): 237-243. https://doi.org/10.1080/1475939x.2010.491234

[12] Ajzen, I. (1985). From intentions to actions: A theory of planned behaviour. In J. Kuhl, J. Beckmann (eds). Action Control from Cognition to Behavior. New York: Springer Verlag https://doi.org/10.1007/978-3-642-69746-3_2 
[13] Venkatesh, V., \& Davis, F. D. (2000). A theoretical extension of technology acceptance model: Four longitudinal field studies. Management Science, 46, 186-204. https://doi.org/ $10.1287 / \mathrm{mnsc} .46 .2 .186 .11926$

[14] Venkatesh, V., Morris, M. G., Davis, G. B., \& Davis, F. D. (2003). User acceptance of information technology: Toward a unified view. MIS Quarterly, 27(3), 425 - 478. https:// doi.org/10.2307/30036540

[15] Cheng, B., Wang, M., Stephen, J. H. Y., Kinshuk, Peng, J. (2011). Acceptance of competency-based workplace e-learning systems: Effects of individual and peer learning support. Computer \& Education, 57(1), 1317-1333. https://doi.org/10.1016/j.compedu.2011.01.018

[16] Yang, K. (2010). Determinants of US consumer mobile shopping services adoption: implications for designing mobile shopping services. Journal of Consumer Marketing, 27(3), 262-270. https://doi.org/10.1108/07363761011038338

[17] Zhou, T., Lu, Y., \& Wang, B. (2010). Integrating TTF and UTAUT to explain mobile banking user adoption. Computers in Human Behavior, 26(4), 760-767. https://doi.org/10. 1016/j.chb.2010.01.013

[18] Rana, A. S. \& Mostafa, A. (2018). "Students Acceptance of Google Classroom: An Exploratory Study using PLS-SEM Approach," International Journal of Emerging Technologies in Learning (iJET), 13(6), pp. 112-123. https://doi.org/10.3991/ijet.v13i06. $\underline{8275}$

[19] Gaskin, J. (2018a). Validity and reliability. Retrived on January 1, 2019 from http://statwiki.kolobkreations.com

[20] Gaskin, J. (2018b). Validity master. Stats Tools Package. Retrived on January 1, 2019 from http://statwiki.kolobkreations.com

[21] Hair, J. F., Black, W. C., Babin, B. J., \& Anderson, R. E. (2014). Multivariate data analysis. Pearson Education Limited (7th ed.). Essex, England: Pearson Education Limited. CBAM Framework. International Journal of Emerging Technologies in Learning, 12(3). https://doi.org/10.3991/ijet.v12i03.6497

[22] Fishbein, M. \& Ajzen, I. (1975). Belief, Attitude, Intention and Behavior: An Introduction to Theory and Research. Reading Mass: Addison-Wesley.

[23] Davis, F.D. (1989). Perceived usefulness, perceived ease of use and user acceptance of information technology. Management Information Systems Quarterly, 13(3), 983-1003. https://doi.org/10.2307/249008

[24] Abu-Al-Aish, A., \& Love, S. (2013). Factors influencing students' acceptance of mlearning: An investigation in higher education. International Review of Research in Open and Distance Learning, 14(5), 82-107. https://doi.org/10.19173/irrodl.v14i5.1631

[25] Ibrahim, M., Ahmad Shidki, M. Y., Wan Salihin Wong, A., \& Fahmi Zaidi, A. R. (2015). Factors contributing pre-school trainees teachers adoption of virtual learning environment: Malaysian evidence. The Turkish Online Journal of Educational Technology, 14(2), 7379.

[26] Wong, K. T., Osman, R., Pauline, S.C.G, Khairezan, R. (2013). Understanding student teachers' behavioural intention to use technology: Technology Acceptance Model (TAM) validation and testing. International Journal of Instruction. 6(1), 89-104.

\section{Authors}

Kung-Teck Wong is an Assoc. Prof at Faculty of Education and Human Development, Sultan Idris Education University (UPSI), Malaysia. Prior to joining UPSI, he was a senior teacher in government schools. He completed his Ph.D. from Univer- 
sity Malaysia Sabah and Post-Doctoral at University of South Australia, Australia (UniSA). He has published extensively in local and international journals. He also serves as reviewer of several local and ISI and SCOPUS indexed journals. In the past five years he has secured many public and private research funding. Wong is interested in statistic studies and also the application of SPSS and AMOS -structural equation modelling in his writing articles and research.

Pauline Swee-Choo Goh received her doctorate from the University of Adelaide and is currently an Associate Professor at the Sultan Idris Education University, Malaysia. Her publications, research interests and expertise are focused on developing and improving both pre-service and beginning teachers' pedagogical knowledge, skills and practice. She is currently authoring a book for beginning teachers in the Malay Language with topics ranging from the preparation of teaching, assessment to classroom discipline. Part of her portfolio also includes her role as the Chief Editor of the university's teacher education journal the Journal of Research, Policy and Practice of Teachers \& Teacher Education.

Norazilawati Abdullah Associate Professor, a presentable, self-motivated and confident lecturer with extensive knowledge on education. Possessing excellent counselling, listening and general communication skills, along with the ability to communicate to students in simple ways on matters regarding teaching and learning. Having exceptional multi-tasking and organisational skills, all of which are imperative when working closely with colleagues. With an already successful academic track record, now looking to accomplish further success in the area of teaching, supervising, research, publication and consultation with a progressive employer such us Sultan Idris Education University (UPSI).

Article submitted 2019-04-11. Resubmitted 2019-05-29. Final acceptance 2019-05-29. Final version published as submitted by the authors. 